\title{
Medical Waste Management Situation at Alexandria Ambulatory Clinics
}

\author{
Sahar Mohamed Soliman ${ }^{1}$, Magda AbdEl-Razek Mostafa ${ }^{2}$, \\ Hesham Zaki Ibrahim ${ }^{3}$ \\ 1(Assist. Professor of Community Health Nursing, Faculty of Nursing, Mansoura University, Egypt). \\ ${ }^{2}$ (Environmental Inspector, Environmental Management Unit/Alexandria Governorate, Egypt) \\ ${ }^{3}$ (Professor of environmental Studies, Institute of Graduate Studies and Research,AlexandriaUniversity, Egypt)
}

\begin{abstract}
Background: Health care waste management is a major challenge in developing countries. Inadequate management of healthcare waste is a serious concern in many developing countries due to the risks posed to human health and to the environment. The aim of the study was to describe the medical waste management situation in ambulatory clinics affiliated to Alexandria governorate's hospitals.

Design:Descriptive cross section study design was used. Convenient sample was used to select the health care providers and waste collector workers by proportion allocation technique. All ambulatory clinics at Alexandria governorate's hospitalsthese clinics were 333 (emergency and outpatient clinics) affiliated to thirty four hospitals were included in the study. Knowledge of health care providers and waste collectors was assessed by structured questionnaire. Observation checklists was used to assess waste management process including structure of waste storage rooms.
\end{abstract}

Result: Results showed improper knowledge and practices related to different issues handling wastes of radioactive materials, chemicals and pressurized containers. In addition, the duration of storage waste was inappropriate.

Recommendations:Establish a medical waste systemto implement the existing legislation, establish waste management team and development of in-service training program for health care workers.

Keywords: Medical waste, Waste management, knowledge, Practices, Waste collectors

\section{Introduction}

The term health-care waste includes all waste that generated within health-care facilities, research centers and laboratories related to medical procedures. In addition, it includes the same types of waste originating from minor and scattered sources. ${ }^{(1)}$ According to the World Health Organization (WHO) the incorrect management of healthcare waste has a high direct risk impacts on: individuals working in health care facilities, and on the surrounding environment and community. ${ }^{(2)}$

Therefore, proper health care waste management is the ethical responsibility of hospital management team and health care staff. ${ }^{(3)}$ Good healthcare waste management in a hospital depends on a dedicated waste management team, good administration, careful planning, underpinning legislation, adequate financing, and full participation by trained staff. ${ }^{(2)}$ WHO emphasizes on controlling and managing medical waste by choosing suitable methods that reflect local conditions of each country. ${ }^{(4)}$

The Egyptian Environmental Protection Law adopted the WHO classification of healthcare settings waste items into "six categories": Sharps (needles, glass vials or scalpel blades); Pathological (anatomical body parts, microbiology cultures and blood samples); Infectious wastes (items contaminated with body fluids and discharges such as dressing, catheters and intravenous lines); Chemical and radioactive wastes (mercury containing instruments and PVC plastics); Pressurized containers and Pharmaceutical waste ${ }^{\cdot(5,6,7)}$

WHO, reported that Primary Health Care centers generate approximately of total waste by $80 \%$ Noninfectious, $15 \%$ Pathological waste and infectious waste, $1 \%$ Sharps waste, $3 \%$ Chemical or pharmaceutical waste and $1 \%$ of Pressurizes cylinders and broken thermometers. ${ }^{(8)}$ Moreover, the developing countries continent generate less amount of health care waste and the proportion of clinical waste to total waste is higher than that of middle developed countries. ${ }^{(9,10)}$

According to international recommendations the various types of waste should be segregated into containers/ bags at the point of generation with color-coded and/or labeled with a symbol. This recommendation stated that black plastic bag for non- hazardous health care waste, red or yellow plastic bag for hazardous health care waste like sharp objects. Liquids or chemicals disposed in the chemical container, which is used once, and should be two third full; double bagging when it is impossible to keep the outer surface of a single bag free from contamination; the second bag should be labeled or color-coded to alert nursing personnel. ${ }^{(11-16)}$

DOI: 10.9790/1959-0505050109 www.iosrjournals.org 1|Page


In addition, the housekeeping personnel are responsible for collecting waste bags separately according to their colors, labeling, closing, and storing each type separately in the intermediate storage room; these bags are then transported using a bar-fence trolley to a final storage room. ${ }^{(17)}$ The personnel in charge of collecting and transporting wastes must be informed to wear gloves. The bags that have been collected must be replaced immediately with new bags and infectious wastes must never be stored in places that are open to the public. Storage time shouldn't exceed 72 hours in winter and 48 hours in summer in temperate climates and in hot climates no longer than 48 hours in cool season and 24 hours in hot season. ${ }^{(12,14-16)}$

Therefore, in accordance with national guideline of waste management, health care workers must be equipped with information and practices in waste management to reduce hospital acquired infections and protect their own health. Because nurses spend more time with patients in the ward than any other member of the health team. This increases their exposure to hospital environmental hazards, primarily biomedical waste, and associated risks. They have important role in minimizing the exposure risk associated with wastes for the other health team members and for the community. ${ }^{(2)}$

\section{Aim of the study \\ The study aimed to describe the medical waste management situation in ambulatory clinics affiliated toAlexandria governorate hospitals. \\ Research questions \\ 1.What is the health care workers knowledge related to medical waste management? \\ 2.What is the actual practice of waste management in the ambulatory clinics? \\ 3. What is the relative quantity of the total medical waste in the studied hospitals and in ambulatory clinics.}

\subsection{Study design:}

\section{Subjects And Method}

Cross sectional design was adopted to carry out this study.

\subsection{Study settings:}

The study was carried out at ambulatory clinics that are affiliated to different governmental hospitals namely; Ministry of Health, University Hospitals, Health Insurance, and Medical Foundation Hospitals.

\subsection{Subjects and sampling:}

\section{Sampling size of ambulatory clinics:}

All the outpatient and emergency clinics (333 clinics) affiliated to 34 hospitals were included in the sample

\section{Health care workers:}

Sampling size of health care workers is calculated for the cross- sectional design; this study required a sample size of 459 health care workers calculated as the following: confidence limit $=5 \%$, population size $=1527$ healthcare workers, confidence level $=95 \%$.expected frequency $=50 \%$ of correct knowledge and design effect $=1 .{ }^{(20}$

Convenient sample was used to select the health care providers and waste collector workers in (outpatient and emergency clinics). Proportion allocation technique was used to identify the selected number from health care providers at each clinic.

\subsection{Data Collection:}

The situation of the waste management was assessed according to "National guidelines of Waste Management Recommendation ".

Tool I: Self-administered structured questionnaire was used to assess health care workers occupational data related to receiving training program pre or post- employment about medical waste management, waste collectors experience's and to assess health care workers Knowledge regarding to waste management. This questionnaire composed of (7) items related to medical waste categories which are; General waste, radioactive waste, chemical waste, infectious waste, sharps waste, pharmaceutical waste and pressurized containers. More over their knowledge about the availability of handout, guideline or instruction about medical waste management in the clinics.

Tool II: Structured observational checklist of actual practice related to waste management in the study settings. This observational checklist was developed to assess practice manner related to waste management at ambulatory clinics. The checklist composed of (9) items as the following; types of generated waste (7 items), practice of segregated medical waste in the studied hospital (5 items), using of international symbols on the segregation tools (one item), practice of medical waste collection (2 items), the direct responsible person of waste collection inside the hospital (4items), uses of safety protective measures during waste collection (one item), availability of safety protective measures (5 items), medical waste transportation (3 items), quantity of waste generated $/ \mathrm{kg} / \mathrm{bed} /$ dayandcharacteristics of the waste storage rooms(14 items).

\subsection{Tool validity}


Content validity of the developed tools was tested by submitting the tools to five experts in "community health nursing and environment studies experts ". Their recommended modifications were done. Furthermore the tools were assessed by conducting a pilot study on 10\% (46) of health care workers. They selected randomly from the same settings and excluded from the studied sample. To estimate the approximate time required for data collection. Accordingly the necessary modification was done, some questions were added and others were clarified or omitted.

\subsection{Data analysis}

- Data were sorted, coded, organized, categorized and then transferred into especially designed formats.

- Analysis was done using appropriate software package SPSS (Stands for Statistical Product and Service Solutions)) version 20.

- Data were presented by using descriptive statistics in the form of frequencies and percentage.

\subsection{Ethical Consideration}

Official permissions were obtained from The Deputy Governor of Alexandria, Directorate of Health Affairs, Chairman of Central Administration, Alexandria University Hospitals and Branch Manager northwest Delta Hospitals Health Insurance. Oral consent was obtained from health care workers. Everyone had the right to withdraw from the research at any time and data considered confidential and used for research purpose only.

\section{Results}

The current results revealed that health care workers including waste collectors didn't receive any training about medical waste management in all studied ambulatory clinics except infection control teams who are not included in the study. sixty percent of waste collectors experiences less than 6 months.

Table (1): Represents the health care workers correct knowledge regarding waste management in the ambulatory clinics. All the studied health care workers including waste collectors in ambulatory clinics were knowledgeable about waste segregation related to color coded containers. While they did not have knowledge related to discarding radioactive and chemical materials except $11.9 \%$ of laboratory technicians. Forty percent of pharmacists have correct knowledge related proper disposal of pressurized containers. Health care workers reported that they did not receive any training regarding medical waste management and related health hazards. Only $13.4 \%$ of nurses mentioned the correct duration of waste storage. Moreover, unavailability of waste management instructions or handouts or guideline was mentioned by all $100 \%$ health care workers.

Table (2): Represents the practice manner in ambulatory clinics of the studied hospitals regarding waste management and segregation of medical waste. It shows that the general waste was segregated in black plastic bags in $87.9 \%$ of the studied ambulatory clinics, while $(11.8 \%)$ segregated in white plastic bags. Infectious waste was segregated in red plastic bags of the studied ambulatory clinics and $2.7 \%$ used both yellow and red plastic bags. It was observed that plastic bags were light plastic, easily broken and were not leak-proof. As regards to sharps, $(58.5 \%)$ of the studied ambulatory clinics used plastic container box, $(14.7 \%)$ used carton container box (leak-proof), while (11.8\%) of them used both container box.

Pressurized containers were segregated in (55.9\%) of the ambulatory clinics with general waste in black colored plastic bags, while $(41.1 \%)$ of them disposed the pressurized containers in red colored plastic bags. Chemical wastes (e.g. solvents, acids, alkalis and left over paints) disposed through sewage at $(87.9 \%)$ of the studied ambulatory clinics, while $(11.7 \%)$ of them were collected in plastic container box. Regarding to international symbols, they were segregated infectious and sharp wastes on $(90.9 \%)$ of the studied ambulatory clinics, while the international symbols weren't observed on pressurized container bags or on laboratory chemical boxes.

Table (3): describes the collection and transportation of medical waste. It was observed that, $(61.5 \%)$ of the studied ambulatory settings their waste plastic bags filled up to (75\%) while (73.2\%) of them their waste bags closed by waste collectors' hands or by plaster. It was noticed that, all waste bags were without identified by label. Waste bags removed immediately after filled by waste collector workers in (46.2\%) of the studied ambulatory clinics.

As regards to protective measures, it was observed that gloves were available at $(97.1 \%)$ of ambulatory clinics, but the waste collector workers weren't wore it. Regarding waste transportation, 55.9\% of the studied ambulatory clinics were using specialized wheeled box inside hospitals followed by waste collector carriers of $(41.1 \%)$ of the studied ambulatory clinics. However, there were no definite sit or temporary sits for handling and collecting waste. There was no a written policy or clear guidelines of waste management and there was no waste management team with clear responsibilities. In addition, (51.5\%) of waste collector senior, were responsible for waste records.

Table (4): describes the characteristics of waste storage rooms in the studied hospitals. It was observed that central waste storage room was found in $(97.1 \%)$ of the studied hospitals but temporary waste storage room wasn't found at any hospital. Regarding location of waste storage rooms $(79.4 \%)$ located far from hospital building, windows found in $(94.1 \%)$ of them and $(82.4 \%)$ of storage rooms were protected from sun rays and almost all walls and floors were ceramic surfaced. Water and sewage sources were $(94.1 \%),(97.1 \%)$ 
respectively. Ferries wheel of cleaning found in $(55.9 \%)$ of the storage rooms. Moreover, the biohazards symbols were observed on $(52.9 \%)$ of storage doors. The duration of waste storage was fixed as 48 hours in $(38.2 \%)$ of the studied hospitals and was fixed as more than 72 hours in other $(38.2 \%)$ of the studied hospitals. The results reveals that $(52.9 \%)$ of the studied hospitals sorted the waste in appropriate way. The majority of the studied hospitals $(97.1 \%)$ contracted with environmental services company regard to final disposal and (76.5\%) of the studied hospitals recorded the delivered and received wastes but incomplete. It was observed that one hospital $2.9 \%$ incinerates the waste outside the hospital.

Table (5): presents the distribution of the relative amount of medical waste generated from ambulatory clinics in the studied hospitals. The results showed that the total observed amount of medical waste generated in the studied hospitals was approximately $4218 \mathrm{~kg} /$ day. The amount of medical waste generated from emergency 530 $\mathrm{kg} /$ day and outpatient clinics were approximately, $456 \mathrm{~kg} / \mathrm{day}$.

Table 1: The correct knowledge of health care workers' regarding medical waste management

\begin{tabular}{|c|c|c|c|c|c|c|c|c|c|c|c|c|}
\hline \multirow[t]{2}{*}{ Items } & \multicolumn{2}{|c|}{$\begin{array}{c}\text { Doctors } \\
143\end{array}$} & \multicolumn{2}{|c|}{\begin{tabular}{|} 
Nursing staff \\
149
\end{tabular}} & \multicolumn{2}{|c|}{$\begin{array}{l}\text { Lab } \\
\text { technicians } \\
42 \\
\end{array}$} & \multicolumn{2}{|c|}{$\begin{array}{c}\text { Pharmacists } \\
30\end{array}$} & \multicolumn{2}{|c|}{$\begin{array}{c}\text { Radiologists } \\
29\end{array}$} & \multicolumn{2}{|c|}{$\begin{array}{l}\text { Waste } \\
\text { collectors } \\
66 \\
\end{array}$} \\
\hline & $\mathbf{N}$ & $\%$ & $\mathbf{N}$ & $\%$ & $\mathbf{N}$ & $\%$ & $\mathbf{N}$ & $\%$ & $\mathbf{N}$ & $\%$ & $\mathbf{N}$ & $\%$ \\
\hline $\begin{array}{l}\text { Segregation of biological } \\
\text { waste at the source }\end{array}$ & 120 & 83.9 & 130 & 87.2 & 30 & 71.4 & 15 & 50 & 20 & 68.9 & 00 & 00 \\
\hline $\begin{array}{l}\text { Using of separated color } \\
\text { coded containers. }\end{array}$ & 143 & 100 & 149 & 100 & 30 & 71.4 & 30 & 100 & 29 & 100 & 66 & 100 \\
\hline $\begin{array}{l}\text { Disposal of sharps and } \\
\text { needles in puncture proof } \\
\text { containers. }\end{array}$ & 120 & 83.9 & 130 & 87.2 & 25 & 59.5 & 20 & 66.6 & 20 & 68.9 & 00 & 00 \\
\hline $\begin{array}{l}\text { Wearing gloves as personal } \\
\text { protective measures. }\end{array}$ & 100 & 69.9 & 120 & 80.5 & 42 & 100 & 15 & 50 & 15 & 51.7 & 00 & 00 \\
\hline $\begin{array}{l}\text { Identifications of some } \\
\text { biological hazards. }\end{array}$ & 80 & 55.9 & 100 & 67.1 & 20 & 47.6 & 15 & 50 & 20 & 68.9 & 5 & 7.5 \\
\hline
\end{tabular}

Table 2: Correct practice of segregated medical waste in the studied ambulatory clinics according to waste management of national guidelines

* More than one response

\begin{tabular}{|l|c|c|}
\hline Waste segregation & $\mathbf{n = 3 3 3}$ & $\mathbf{\%}$ \\
\hline General waste & & \\
\hline - Black plastic bags & 293 & 87.9 \\
\hline - White plastic bags. & 39 & 11.7 \\
\hline Infectious waste & 323 & \\
\hline Red plastic bags & 9 & 2.9 \\
\hline Red and Yellow plastic bags & & \\
\hline Sharps waste & 195 & 58.5 \\
\hline -Plastic container box & 49 & 14.7 \\
\hline -Carton container box (leak-proof). & & \\
\hline Pressurized containers & 19 & 55.9 \\
\hline - Black Plastic bag. & 9 & 2.7 \\
\hline - White Plastic bag. & 137 & 41.1 \\
\hline - Red Plastic bag. & & \\
\hline Chemical wastes & 293 & 87.9 \\
\hline - To general sewage & 39 & 11.7 \\
\hline - Collected in plastic container boxes & 303 & 90.9 \\
\hline $\begin{array}{l}\text { Presence of international symbols on the } \\
\text { Segregation bags. }\end{array}$ & & \\
\hline
\end{tabular}

Table 3: Practice of waste collection and transportation process in the studied ambulatory clinics regarding national guidelines of waste management.

\begin{tabular}{|l|c|c|}
\hline Items & $\mathrm{n}=333$ & $\%$ \\
\hline Process of waste collection & & \\
\hline - Bag filling up to75\% & 205 & 61.5 \\
\hline -Close the bags & 244 & 73.2 \\
\hline -Label the bags & 333 & 100 \\
\hline Time of collection & & \\
\hline - Immediate after bag filled. & 154 & 46.2 \\
\hline -Once/ working shift & 58 & 17.4 \\
\hline -Twice /day & 39 & 11.7 \\
\hline -Three times /day & 19 & 5.7 \\
\hline
\end{tabular}




\begin{tabular}{|l|c|c|}
\hline -Once/ day & 19 & 5.7 \\
\hline Waste transportation inside hospitals by: & & \\
\hline -Specialized wheeled box & 186 & 55.9 \\
\hline -Waste collector carriers & 138 & 41.4 \\
\hline -Waste wheeled trolley & 9 & 2.7 \\
\hline
\end{tabular}

Table 4: Characteristics of waste storage rooms in the studied hospitals

\begin{tabular}{|l|l|l|}
\hline Items & $\mathbf{n = 3 4}$ & $\mathbf{\%}$ \\
\hline Waste storage rooms location & & \\
\hline Far of hospital buildings & 27 & 79.4 \\
\hline Near of outpatient clinics & 7 & 20.5 \\
\hline Ventilation & & \\
\hline Presence of windows & 32 & 94.1 \\
\hline Presence of air condition & 2 & 5.9 \\
\hline Protected from sun rays & 28 & 82.4 \\
\hline Walls ceramic surfaced & 33 & 97.1 \\
\hline Floor ceramic surfaced & 34 & 100 \\
\hline Presence of water source & 32 & 94.1 \\
\hline Presence of sewage source & 33 & 97.1 \\
\hline Presence of ferries wheel of cleaning tools & 19 & 55.9 \\
\hline Presence of biohazards symbols on storage door & 18 & 52.9 \\
\hline Duration of waste storage inside storage room & & \\
\hline-24 hours & 2 & 5.9 \\
\hline-48 hours & 13 & 38.2 \\
\hline-72 hours & 6 & 17.6 \\
\hline- More than 72 hours & 13 & 38.2 \\
\hline
\end{tabular}

Table 4: Distribution of the total medical waste (MW) / Kg/bed/day in emergency and outpatient clinics in studied hospitals

\begin{tabular}{|c|c|c|c|c|c|c|c|}
\hline $\begin{array}{l}\text { Code of } \\
\text { hospital }\end{array}$ & $\begin{array}{r}\text { Total MW/ } \\
\text { Kg/ day }\end{array}$ & $\begin{array}{rr}\text { Total } & \begin{array}{l}\text { MW } \\
\text { from }\end{array} \\
\text { Emergency } \\
/ \text { Kg } \\
\text { day }\end{array}$ & $\begin{array}{rr}\text { Total } & \begin{array}{r}\text { MW } \\
\text { from }\end{array} \\
\text { Outpatient } \\
\text { clinics / } \\
\text { Kg/ } \\
\text { day }\end{array}$ & 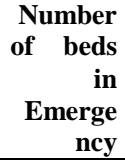 & $\begin{array}{r}\text { Number of } \\
\text { beds in } \\
\text { Outpatient } \\
\text { clinics }\end{array}$ & $\begin{array}{r}\text { Amount of MW } \\
/ \mathrm{Kg} / \mathrm{bed} / \text { day in } \\
\text { Emergency }\end{array}$ & $\begin{array}{r}\text { Amount of } \\
\text { MW/ Kg/ } \\
\text { bed/day in } \\
\text { clinics }\end{array}$ \\
\hline 1 & 85 & 15 & 8 & 4 & 11 & 3.75 & 0.8 \\
\hline 2 & 60 & 22 & 0 & 15 & 0 & 1.5 & 0 \\
\hline 3 & 43 & 8 & 8 & 3 & 9 & 2.7 & 0.9 \\
\hline 4 & 50 & 5 & 12 & 3 & 2 & 1.7 & 6 \\
\hline 5 & 125 & 8 & 4 & 5 & 4 & 1.6 & 1 \\
\hline 6 & 10 & 5 & 0 & 5 & 0 & 1 & 0 \\
\hline 7 & 125 & 17 & 11 & 10 & 13 & 1.7 & 0.8 \\
\hline 8 & 30 & 6 & 3.5 & 4 & 9 & 1.5 & 0.4 \\
\hline 9 & 130 & 10 & 18 & 4 & 6 & 2.5 & 3 \\
\hline 10 & 180 & 12 & 30 & 4 & 13 & 3 & 2.3 \\
\hline 11 & 50 & 29 & 6 & 5 & 11 & 5.8 & 0.5 \\
\hline 12 & 120 & 15 & 11 & 10 & 16 & 1.5 & 0.7 \\
\hline 13 & 30 & 2 & 3.5 & 5 & 2 & 0.4 & 1.75 \\
\hline 14 & 65 & 12 & 4 & 5 & 11 & 2.4 & 0.4 \\
\hline 15 & 70 & 10 & 4 & 8 & 4 & 1.25 & 1 \\
\hline 16 & 170 & 20 & 8 & 15 & 16 & 1.3 & 0.5 \\
\hline 17 & 185 & 18 & 15 & 10 & 16 & 1.8 & 0.9 \\
\hline 18 & 25 & 5 & 4 & 5 & 5 & 1 & 0.8 \\
\hline 19 & 100 & 18 & 21 & 10 & 12 & 1.8 & 1.75 \\
\hline 20 & 1000 & 60 & 23 & 20 & 13 & 3 & 1.8 \\
\hline 21 & 80 & 7 & 10 & 5 & 6 & 1.4 & 1.7 \\
\hline 22 & 165 & 16 & 20 & 8 & 7 & 2 & 2.9 \\
\hline 23 & 170 & 21 & 8 & 4 & 4 & 5.3 & 2 \\
\hline 24 & 100 & 15 & 10 & 5 & 13 & 3 & 0.8 \\
\hline 25 & 50 & 10 & 15 & 4 & 12 & 2.5 & 1.25 \\
\hline 26 & 45 & 0 & 18 & 0 & 6 & 0 & 3 \\
\hline 27 & 190 & 20 & 8 & 10 & 10 & 2 & 0.8 \\
\hline 28 & 70 & 25 & 46 & 8 & 11 & 3.1 & 4.2 \\
\hline 29 & 400 & 10 & 25 & 10 & 6 & 1 & 4.2 \\
\hline
\end{tabular}


Medical Waste Management Situation at Alexandria Ambulatory Clinics

\begin{tabular}{|c|c|c|c|c|c|c|c|}
\hline 30 & 170 & 100 & 58 & 20 & 7 & 5 & 8.2 \\
\hline 31 & 30 & 5 & 10 & 3 & 12 & 1.7 & 0.8 \\
\hline 32 & 25 & 2 & 18 & 2 & 11 & 1 & 0.2 \\
\hline 33 & 40 & 1 & 3 & 5 & 4 & 0.75 \\
\hline 34 & 30 & 1 & 13 & 2 & 12 & 0.5 & 1.1 \\
\hline Total & 4218 & 530 & 456 & 236 & 294 & Mean =2.1 & Mean=1.7 \\
\hline
\end{tabular}

\section{Discussion}

Proper management measure of health care waste is a key in controlling and reducing nosocomial infections inside the health care settings and outside the environment. ${ }^{(18,19)}$

Regarding to the occupational data, the results of the present study revealed that there is a lack of educational training programs for health care workers pre and post-employment regarding medical waste management and related health hazards. The educational training program was given only to infection control team as reported by health care workers. Moreover, waste collector workers experience was less than 6 months due to the turn off the housekeepers who deal with collection and transportation of waste without job description.This result is in the same line with Abdulla et al. (2008) who reported that $29 \%$ of the hospitals in northern Jordan did not provide training to health care workers regarding waste management and its related hazards; $57 \%$ of hospitals provided limited training for support staff (maintenance engineers and cleaning workers). ${ }^{(20)}$

This result is agreement with results of other studies conducted in Alexandria, Dakahlia, Quna ${ }^{(21)}$ and El-Behera governorates ${ }^{(22)}$ in Egypt, Malaysia ${ }^{(23)}$, Libya ${ }^{(24)}$, and Kenya ${ }^{(19)}$ these studies revealed lack of programs training related to waste management for health care providers. While the results in contrast with the findings of Birpinar et al., (2008) who found that, 98\% of Istanbul, hospitals organized courses for their waste collector personnel, and health care providers doctors, nurses, and technicians; regarding medical waste management sixty three percent of healthcare providers organized courses at least once per month, while $31 \%$ of them organized courses at least twice a year. ${ }^{(25)}$ In addition, Askarian et al., (2004) reported that $60 \%$ of hospitals in Iran provided some training for cleansing staff; however, newly hired waste management personnel were not trained properly. While there are effective training programs and educational plans related to medical waste management for all staff in USA. ${ }^{(26)}$ Proper training must be carried out with hospital employees to develop awareness of health, safety and environmental issues. ${ }^{27}$

The knowledge of health care workers and waste collectors' in the studied ambulatory clinics was not in line with national guidelines of waste management. This deficit of knowledge could be attributed to one or more causes, which include the lack of exposure to pre -employment orientation programs related to waste management, lack of refresher conferences during employment and unavailability of waste management instructions or handouts to be used as a guide. Additionally, there wasn't an assigned person for managing medical waste and even the practice of assigned person was not based on scientific knowledge. While study in Iran reported that $46.7 \%$ of their hospitals assigned a person to be responsible for medical waste management (26).

Although the medical waste is regulated by laws in Egypt and classified as a hazardous waste by the law number 4 of 1994 and amended by low 9 of 2009 and executive regulation, the staff in healthcare settings were unaware of this legislation due to the absence of written policies and clear guidelines, in addition to inefficient training programs.

As regards to practice manner of segregated medical waste, the results of the present study revealed that the types of waste generated from clinics such as general, infectious and sharps were disposed in the same line with national guidelines of waste management . These segregated practices were similar to the medical waste management practices reported in kingdom of Bahrain, and in China where the segregation practices have been applied as follows: infectious waste was collected in yellow and red bags; municipal waste was collected in black bags; and sharps were collected in plastic containers. ${ }^{(28,29)}$ These results were supported by WHO recommendations, which reported that using of color coding system is important to enhance segregation practices. Careful segregation of waste into different categories helps to minimize the quantities of hazardous waste. ${ }^{(2,19)}$ Segregating hazardous from nonhazardous waste reduces the risks of infection.

While the types of waste such as pressurized containers and chemical waste were disposed by improper way and weren't accordance with national guidelines of waste management. Because more than half of segregated pressurized containers were disposed in black colored plastic bag and the chemical wastes was disposed through sewage by the majority of the studied ambulatory clinics. International symbols were found only on segregated 
infectious and sharps wastes. However, pressurized containers and laboratory chemical wastes weren't segregated as national guidelines of waste management.

As regards practice of waste collection and transportation process, the present results explored that about one third of the studied ambulatory clinics did not follow the national waste management guidelines recommendations. Regarding Labeling of waste containers or bags is a recommended practice to ensure that each waste category is easily identified, also to enable managers and other personnel to trace any waste bag to its source if a problem is found ${ }^{(19)}$.

As regards to protective measures, the present study revealed that gloves were available at the majority of the studied hospitals, but the waste collector workers weren't wore them because gloves hinder their work. Moreover, they didn't wear protective clothes during handling the medical waste.

Results of the present study is in agreement with other studies conducted in Bangladesh and India (2013) they found that there was a poor practice among health care waste. ${ }^{(14,19,30,31)}$

The present results indicated that all the studied hospitals have temporary storage room, but had central storage rooms that weren't identical to the measurements specifications. The maximum storage period in the central storage rooms was more than 2 days without refrigerated conditions in more than one third of the studied hospitals in spite of seasonal variation where negative impacts occurs to public health and environment. This result is in contrast with the medical waste national guidelines ${ }^{(19,32,33)}$ which recommended that, medical wastes can be stored for a week in a refrigerated area $\left(3^{0}\right.$ to $\left.8^{0} \mathrm{C}\right)$, which wasn't available in studied hospitals. It was observed that all the hospitals had fixed duration for waste storage irrespective of the types of waste or season, more than one third of hospitals store the waste for more than 72 hours while, the storage time for infectious medical shouldn't exceed 72 hours in winter and 48 hours in summer in temperate climates and in hot climates no longer than 48 hours in cool season and 24 hours in hot season. ${ }^{(12,14-16)}$

Therefore, medical waste should be handled, stored, transported and disposed of in a controlled manner to safeguard public health and to prevent environmental pollution. ${ }^{(34)}$. But the management of medical waste particularly in developing countries is often poor with difficulties; which is creating inevitable risks to the health care workers, publics and the environment ${ }^{(33,35)}$. After the medical wastes are segregated and collected, the staff should move them from the location of generation to waste storage room, where they balanced, until they go for final disposal either on- or off-sites. ${ }^{(19)}$ The storage location, storage containers and storage management have a direct impact on the resulting environmental and health risks at the hospital, which must be sanitized and secured for access only to authorized personnel. ${ }^{(19)}$

With respect to the amount of medical waste /day / bed, the results of the present study revealed that the amount of medical waste produced in the studied hospitals was approximately $4218 \mathrm{~kg} / \mathrm{day}$. The amount of medical waste generated from ambulatory clinics was approximately (emergency530 kg/day, and outpatient clinics $456 \mathrm{~kg} /$ day). The average amount was $2.1 \mathrm{~kg} /$ day / bed in emergency and $1.7 \mathrm{~kg} / \mathrm{day} /$ bed in outpatient clinics. These findings are in the same line with the results of India, England ${ }^{(30)}$, and Greece, which reported an average amount of medical waste generation about $1.9 \mathrm{~kg} / \mathrm{bed}$ day ${ }^{\left({ }^{(3)}\right.}$ According to a summary by Diaz et al. (2008). The total amount of healthcare waste generated in selected hospitals in developing countries varied from 0.016 to $3.23 \mathrm{~kg} / \mathrm{bed}$ day. ${ }^{(37)}$

The Africa developing countries such as: (South Africa ${ }^{(5)}$, Algeria ${ }^{(37)}$, Egypt ${ }^{(25)}$, Libya ${ }^{(35)}$ and Asia (Bangladesh ${ }^{(38)}$, Mongolia ${ }^{(39)}$ generate lower amount of health care waste, but the proportion of clinical waste among total waste much higher than that of middle developed countries in Europe. (Croatia ${ }^{(6)}$, Greece ${ }^{(40)}$ )

World Health Organization reported the product of healthcare waste / $\mathrm{kg} / \mathrm{bed} / \mathrm{day}$ of the following quantities; North America produces (7-10 kg), South America produces $3 \mathrm{~kg}$. Western Europe $(3-6 \mathrm{~kg})$, Eastern Europe (1.4-2 kg). In Asia, the richest countries produce $2.5 \mathrm{~kg}$ and the poorest countries $(1.8-2 \mathrm{~kg}$.). ${ }^{(39)}$ Generally, quantities of the waste generation rate in health care facilities depend on type and size of health care facilities, availability of instrumentation and general condition of their area, the ratio of disposable items in use and number of days spent on patients care. ${ }^{(16,38,41-43)}$

\section{Conclusion \& recommendations}

\section{Conclusion}

This study concluded that there was proper knowledge among all health care workers related to waste segregation regarding general, infectious and sharps waste while the improper knowledge was obviously related to radioactive and chemical materials, pressurized containers and pharmaceutical waste even among radiologists, pharmacists, and laboratory technicians. While waste collectors have knowledge related to color coded bags. In 
addition to the absent of written policies or clear guidelines of waste management and absent of waste management team. As regards to practice of waste management steps, there was poor practices in half of the studied ambulatory clinics related to sorted, collected and transported the medical waste. All the storage waste rooms were inappropriate, the majority of the studied hospitals had records for delivered and received wastes but these records were incomplete. There is contraction with an environmental services company.

\section{Recommendations}

Based on the findings and conclusion drawn of this study the following recommendations are explored:

- Establish a medical waste systemto implement the existing legislation.

- Establish waste management team

- Development of in-service training program for health care workers.

- Written policies or clear guidelines of waste management should be available at ambulatory clinics.

\section{References}

[1].World Health Organization (2014). Safe management of waste. WHO care activities. $2^{\text {nd }}$ ed.

[2].World Health Organization (2005). Management of Solid Health - Care Waste at Primary Health Care

Centers, a Decision Making Guide, Geneva.

[3].Vijaya Kumar Goddu, KavitaDuvvuri ,VidyaKaumudiniBakki (2007). A Critical Analysis of Healthcare Waste Management in Developed and Developing Countries: Case Studies from India and England, Proceedings of the International Conference on Sustainable Solid Waste Management, Chennai, India. 134- 141.

[4].Al-Khatib, I.A. and Sato, C. (2009) 'Solid health care waste management status at health care centers in the west bank - Palestinian territory', Waste Management, 29(8), pp. 2398-2403. doi: 10.1016/j.wasman.2009.03.014.

[5].Ministry of Health (2001). Lists of hazardous wastes annexed to the Ministry of Health and Population, 192.

[6].Egyptian Prime Minister (2009). Executive Decree No. 338/1995 and No. 1741/2005 concerning the Environmental Law.1994; 4.Government Printing House, Cairo, and the amended by executive regulation.

[7].World Health Organization (2003). Safe Management of Waste from Health Care Activities, Geneva, Western Pacific Regional Office Preparedness; 58-64.

[8].World Health Organization (2006). Waste Management during routine medical activities. Available at; http:www.wastemanagement/ WHO/health-care waste.

[9].Nemathaga, F., Maringa, S., \&Chimuka, L. (2008). Hospital solid waste management practices in Limpopo province, South Africa: A case study of two hospitals. Waste Management, 28(7), 1236-1245. doi:10.1016/j.wasman.2007.03.033.

[10].Rushbrook P., Chandra C., Gayton S. (2000). Starting health-care waste management in medical institutions. Health-care waste practical information series. WHO Regional Office for Europe, European Centre for Environment and Health, Copenhagen.

[11].World Health Organization (2006). Healthcare Waste Management Available at; http:// www.healthcarewaste.org/en/128_hcw_categ.html>.

[12].Ministry of health \& ministry of environmental affairs (2010). Medical Waste Integrated Management.

[13].Askarian, M., Heidarpoor, P., \&Assadian, O. (2010). A total quality management approach to healthcare waste management in Namazi hospital, Iran. Waste Management, 30(11), 2321-2326. doi:10.1016/j.wasman.2010.06.020

[14].World Health Organization (2005). Preparation of National Health-Care Waste Management Plans in Sub-Saharan Countries Guidance Manual Secretariat of the Basel Convention and World Health Organization.

[15].International Committee of the Red Cross (2011). Medical waste management.avenue de la Paix, Geneva, Switzerland, ICRC.

[16].Askarian, M., Vakil, M., Kabir, G. (2004). Hospital waste management status in university hospitals of Fars provenance, Iran. Environmental Health Research; 14 (4): 295-305.

[17].Hossain, M. S., Santhanam, A., NikNorulaini, N. A., \& Omar, A. K. M. (2011). Clinical solid waste management practices and its impact on human health and environment - A review. Waste Management, 31(4), 754-766. doi:10.1016/j.wasman.2010.11.008

[18].Hassan, M. M., Ahmed, S., Rahman, K. A., \&Biswas, T. (2008). Pattern of medical waste management: Existing scenario in Dhaka city, Bangladesh. BMC Public Health, 8(1), 36. doi:10.1186/1471-2458-8-36.

[19]. Ministry of health, the National Health Care Waste Management Plan, 2008-2012, KENYA.

[20].Abdulla, F., Abu Qdais, H., \& Rabi, A. (2008). Site investigation on medical waste management practices in northern Jordan. Waste Management, 28(2), 450-458. doi:10.1016/j.wasman.2007.02.035.

[21].Mohamed Soliman, S., \& Ibrahim Ahmed, A. (2007). Overview of biomedical waste management in selected Governorates in Egypt: A pilot study. Waste Management, 27(12), 1920-1923. doi:10.1016/j.wasman.2006.08.009.

[22].Sawalem, M., Selic, E., \&Herbell, J. . (2009). Hospital waste management in Libya: A case study. Waste Management, 29(4), 13701375. doi:10.1016/j.wasman.2008.08.028.

[23].Mohamed, L. F., Ebrahim, S. A., \& Al-Thukair, A. A. (2009). Hazardous healthcare waste management in the kingdom of Bahrain. Waste Management, 29(8), 2404-2409. doi:10.1016/j.wasman.2009.02.015Zhang Yong, Xiao Gang, Wang Guanxing, Zhou Tao\& Jiang Dawei (2009). Medical waste management in China: A case study of Nanjing, Waste Management, 29:1376-1382.

[24].WHO (2010). Safe management of wastes from health-care activities, Op. cit.

[25].Coker, A., Sangodoyin, A., Sridhar, M., Booth, C., Olomolaiye, P., \& Hammond, F. (2009). Medical waste management in Ibadan, Nigeria: Obstacles and prospects. Waste Management, 29(2), 804-811. doi:10.1016/j.wasman.2008.06.040.

[26].Askarian, M., Vakili, M., \&Kabir, G. (2004). Results of a hospital waste survey in private hospitals in Fars province, Iran. Waste Management, 24(4), 347-352. doi:10.1016/j.wasman.2003.09.008.

[27].Abd El-Salam, M. M. (2010). Hospital waste management in El-Beheira Governorate, Egypt. Journal of Environmental Management, 91(3), 618-629. doi:10.1016/j.jenvman.2009.08.012.

[28].Kontogianni, S., Xirogiannopoulou, A., \&Karagiannidis, A. (2008). Investigating solid waste production and associated management practices in private dental units. Waste Management, 28(8), 1441-1448. doi:10.1016/j.wasman.2007.05.025.

[29].Hagen, D. L., Al-Humaidi, F., \& Blake, M. A. (2001). Infectious waste surveys in a Saudi Arabian hospital: An important quality improvement tool. American Journal of Infection Control, 29(3), 198-202. doi:10.1067/mic.2001.114224

[30].Diaz, L. F., Savage, G. M., \&Eggerth, L. L. (2005). Alternatives for the treatment and disposal of healthcare wastes in developing countries. Waste Management, 25(6), 626-637. doi:10.1016/j.wasman.2005.01.005. 


\section{Medical Waste Management Situation at Alexandria Ambulatory Clinics}

[31].Bendjoudi, Z., Taleb, F., Abdelmalek, F., \&Addou, A. (2009). Healthcare waste management in Algeria and Mostaganem department. Waste Management, 29(4), 1383-1387. doi:10.1016/j.wasman.2008.10.008.

[32].Ndiaye, P., Fall, C., Diedhiou, A., Tal-Dial, A. \&Diedhiou, O. (2003). Biomedical waste management in the Regional Hospital Center of Ziguinchor. Sante, 13 (3): 171-176.

[33].Burd, M. (2005). Reducing the risks related to the handling and disposal of healthcare waste. Prof. Nurses, 20 (8): $40-42$.

[34]. Patwary, M.A., O’Hare, W.T., Street, G., Elahi, K.M., Hossain, S.S\&Sarker, M.H (2009). Health and safety perspective on medical waste management in a developing country: a case study of Dhaka City. FAIM, University of Teesside, ISBN. 2009; 2-4

[35].Patil, G. V., \&Pokhrel, K. (2005). Biomedical solid waste management in an Indian hospital: A case study. Waste Management, 25(6), 592-599. doi:10.1016/j.wasman.2004.07.011.

[36]. Sawalem, M., Selic, E., \&Herbell, J. . (2009). Hospital waste management in Libya: A case study. Waste Management, 29(4), 13701375. doi:10.1016/j.wasman.2008.08.028.

[37].Shinee, E., Gombojav, E., Nishimura, A., Hamajima, N., \& Ito, K. (2008). Healthcare waste management in the capital city of Mongolia. Waste Management, 28(2), 435-441. doi:10.1016/j.wasman.2006.12.022.

[38]. Rushbrook P., Chandra C. \&Gayton S. (2000). Starting health-care waste management in medical institutions. Health-care waste practical information series. WHO Regional Office for Europe, European Centre for Environment and Health, Copenhagen.

[39].Bdour, A., Altrabsheh, B., Hadadin, N., \& Al-Shareif, M. (2007). Assessment of medical wastes management practice: A case study of the northern part of Jordan. Waste Management, 27(6), 746-759. doi:10.1016/j.wasman.2006.03.004.

[40].Marinković, N., Vitale, K., Holcer, N. J., Džakula, A., \&Pavić, T. (2008). Management of hazardous medical waste in Croatia. Waste Management, 28(6), 1049-1056. doi:10.1016/j.wasman.2007.01.021.

[41].Rasheed, S., Iqbal, S.\&Baig LA., (2005). Hospital waste management in the teaching hospitals of Karachi. J. Pak. Med. Assoc. 55 (5), $192-195$.

[42].Masum A. Patwary, William Thomas O’Hare, Mosharraf H. \&Sarker (2011). Occupational accident: An example of fatalistic beliefs among medical workers in Bangladesh, waste Safety Science.

[43].Gulf Research Center (2006). Solid Waste Management, Green Gulf Report. Gulf Research Center Publications, Dubai, United Arab Emirates, 6: 71- 79 . 